\title{
THE RELATIONSHIP BETWEEN CIVIC FACTORS AND THE MIDDLE PROFICIENCY LEVEL OF CIVIC KNOWLEDGE
}

\author{
Ireta Čekse \\ University of Latvia, Latvia \\ Reinis Alksnis \\ University of Latvia, Latvia
}

\begin{abstract}
This study explores the relationship between civic and citizenship factors and the middle proficiency level of students' civic knowledge in the Baltic countries: Estonia, Latvia and Lithuania. The study uses large scale data from the IEA's International Civic and Citizenship Education Study (ICCS) 2016. According to ICCS 2016, 39\% of students from the three Baltic countries and only $26 \%$ of students from the Nordic countries had a middle proficiency level of civic knowledge. This middle proficiency level is the largest group in comparison to other levels. Therefore, the study aims to recognise the differences between the highest and lowest achievements in the middle proficiency level of civic knowledge and to examine the relationship between factors such as background, values, behaviour, citizenship activities and attitudes. Multivariable linear regression was used for the data analysis, creating several models. The results show that there are different factors associated with the highest and lowest achievements in the middle proficiency level. For example, the results indicate that students with a lower proficiency level participated in illegal protest activities more often and had lower critical thinking skills. Moreover, the research investigates differences inside the middle proficiency level of civic knowledge and between the lowest middle-level students and students from the lower level of civic knowledge.
\end{abstract}

Keywords: citizenship education, civic knowledge, citizenship activities, gender equality, Baltic countries, ICCS 2016, multivariable linear regression.

\section{Introduction}

The results of the International Association for the Evaluation of Educational Achievement's (IEA) International Civic and Citizenship Education Study (ICCS) 2016 (Schulz et al., 2017) show that 30\% of students from the three Baltic countries (Estonia, Latvia and Lithuania) had a higher proficiency level of civic knowledge, 39\% a middle proficiency level, $24 \%$ a basic proficiency level and 7\% a lower or below lower proficiency level. The middle proficiency level is the biggest group in the classification. The large number of students who are in the middle proficiency level allows us to think about factors 
Čekse \& Alksnis, 2021. The Relationship Between Civic Factors and the Middle Proficiency Level of Civic Knowledge

that affect students' knowledge. In other words, this study assumes that there might be differences between students inside the middle level of civic knowledge. Indicating the differences between the upper-middle level and the lower-middle level will allow teachers to predict these factors and plan activities that raise students up to a higher level of civic knowledge. Highlighting the predictors that bring success in citizenship education is essential for citizenship education policy makers and also for teachers. Therefore, the research aims to recognise the differences between the highest and lowest achievements in the middle proficiency level of civic knowledge and to examine the relationship between factors such as the values, behaviour and attitudes of students.

Civic knowledge creates the cognitive component of citizenship, which helps to create an open classroom climate that promotes higher levels of civic knowledge and political efficacy (Torney-Purta, Lehman, Oswald, \& Schulz, 2001) and develops such skills as interpreting political communication and promoting engagement in daily citizenship activities (Isac, Maslowski, \& van der Werf, 2011; Kirlin, 2003). Another interpretation explains civic knowledge as outcomes from the educational system at the school, classroom and student levels (Isac et al., 2011; Creemers, 1994).

In civic and citizenship education, students' level of civic knowledge is often used as a factor to explain differences between divergent groups in comparative education studies. For example, their level of civic knowledge is used as a dependent variable to investigate differences between immigrant and native-born groups (Zhu \& Chiu, 2020; Carolyn, Torney-Purta, \& Wilkenfeld, 2015), socioeconomic compositions (Diego, Banerjee, Treviño, \& Villalobos, 2020) and open classroom climates (Knowles \& McCafferty-Wright, 2015; Lihong \& Biseth, 2016).

Civic knowledge is necessary for civic participation and engagement (Zhu \& Chiu, 2020). Levels of civic knowledge are reflected in citizenship activities, which are highlighted as important content in the context of European digital citizenship (Council of Europe, 2019). However, when considering citizenship activities, one can comprehend people's political and social participation in society (Whiteley, 2014; Manning \& Edwards, 2014; Mycock \& Tonge, 2012), community- and school-level engagement (Schulz et al., 2017; Torney-Purta, 2002), citizenship self-efficacy (Manganelli \& Lucidi, 2015; Manganelli, Lucidi, \& Alivernin, 2014) and ethical norms and values (Lin, 2015; Veugelers \& Groot, 2019).

\section{Methodology}

The aim of the research is to investigate the relationship between civic and citizenship factors and the middle proficiency level of students' civic knowledge in the Baltic countries. 
In doing so, three key research questions are raised:

1. Which are the related factors in the middle proficiency level of students' civic knowledge in the Baltic countries?

2. What are the differences between factors at the lower and higher ends of the middle proficiency level of students' civic knowledge?

3. What are the differences between the Baltic countries' results?

Data was taken from the IEA ICCS 2016 study for the analysis (data available at https://doi.org/10.3886/ICPSR37147.v1). The ICCS 2016 study is the fourth ICCS study that aimed to find out the ways in which young people are prepared to undertake their roles as citizens (Schulz, Ainley, Losito, \& Agrusti, 2016, p. 34).

The following numbers of students $(\mathrm{N}=3273)$ were sampled from ICCS 2016: 740 from Estonia (EST), 1190 from Latvia (LVA) and 1343 from Lithuania (LTA). The authors obtained the results from the appropriate sampling weights and variance estimations based on the rules set out in the ICCS 2016 User Guide for the International Database (Köhler, Weber, Falk, Schulz, \& Carstens, 2018).

ICCS 2016 presents students' achievements in citizenship education. Together with attitudes towards democratic perceptions of citizenship activities and values in the student questionnaire, civic knowledge is measured in a student cognitive test. Each country's students' civic knowledge is divided into four levels, ranging from A (higher) to D (lower). Each level has an amplitude score (Schulz et al., 2017). This research observes the middle proficiency level of students' civic knowledge and looks for related factors at the lower and higher ends of the middle proficiency level. Students who scored 479-563 points in the ICCS 2016 study are classified in the middle proficiency level. To highlight any variation in factors within the middle proficiency level, it was divided into two groups: lower (479-520 points) and higher (521-563 points).

To divide students into levels of civic knowledge, the mean of five plausible values that were provided with the dataset was used. In the regression models, each of the plausible values was used as a dependent variable separately, and then the results were aggregated. In total, 15 predictors were considered as explanatory variables (see Table 1), of which five (S_GENDER, C_URBAN, C_SCSIZE_CAT, S_TLANG and S_ISCED) are categorical and the other ten are continuous variables obtained from Likert scale questionnaires with item response theory (provided in the dataset). 
Čekse \& Alksnis, 2021. The Relationship Between Civic Factors and the Middle Proficiency Level of Civic Knowledge

Table 1 Descriptions of Explanatory Variables

\begin{tabular}{|c|c|}
\hline Explanatory variable & Description \\
\hline S_GENDER & Student's gender \\
\hline C_URBAN & Urbanisation level \\
\hline C_SCSIZE_CAT & School size (by number of students) \\
\hline S_ABUSE & Experience of physical and verbal abuse at school \\
\hline S_INTACT & Perception of student's interactions at school \\
\hline S_STUTREL & Perception of student-teacher relations at school \\
\hline S_CNTATT & Positive attitudes towards their country of residence \\
\hline S_ETHRGHT & Endorsement of equal rights for all ethnic/racial groups \\
\hline S_CITCON & Perception of the importance of conventional citizenship \\
\hline S_VALPARTS & Perception of the value of participation at school \\
\hline S_GENEQL & Endorsement of gender equality \\
\hline S_ILLACT & Expected participation in illegal protest activities \\
\hline S_LEGACT & Expected participation in legal activities \\
\hline S_TLANG & Test language use at home \\
\hline S_ISCED & Expected educational attainment \\
\hline
\end{tabular}

First, the authors investigated the subset of all B-level students with some descriptive statistics. Then a multivariable regression analysis was conducted to inspect which factors are associated with students' civic knowledge. Since regression models were made with each plausible value separately, due to the variance between plausible values, standard errors of regression coefficients were larger and, consequently, the corresponding confidence intervals were wider than if only one response variable had been used. From p-values and confidence intervals alone, it would appear that most of the predictors in this analysis are statistically insignificant. However, to obtain deeper insight into the possible associations between civic knowledge and chosen predictors, the authors used subsampling, i.e. instead of using a stepwise algorithm to choose the predictors to keep in the final model, 1000 random subsamples were taken with 150 students each and a regression model was done with these subsamples. The authors could thereby observe which predictors were significant more often than they would only by chance, which is approximately 50 if a 5\% confidence level is used. These predictors were then put into the final model. The results of each model are shown in the tables below. To judge the importance of predictors and their association with response variables, confidence intervals were used. If the interval is symmetric (around zero), it is considered insignificant; however, when it is asymmetric, then signs of possible association may be determined. 


\section{Research Results}

To obtain an overall comparison between the Baltic countries, 95\% confidence intervals were calculated for the mean civic knowledge of students with a middle proficiency level of civic knowledge. These were (518.32, 521.32) for Latvia, (520.48, 523.36) for Lithuania and (521.80, 525.49) for Estonia. One could conclude that the means of Latvia and Estonia are significantly different at a 95\% significance level since the intervals do not overlap, however it should be taken into account that quite large sample sizes were used. For large enough samples, even the tiniest differences will be significant. Therefore, we rather choose to base our conclusions on confidence intervals instead of p-values which can sometimes be misleading, although both are reported in this study. To get a more robust central tendency measure, medians were also calculated: 519.45 for Latvia, 523.4 for Lithuania and 526.18 for Estonia. While that of Latvia lies in the middle of the confidence interval for the mean, the medians for Lithuania and Estonia are above the corresponding confidence intervals, indicating negative skewness. The distribution for Latvia seems to be fairly symmetrical, but Lithuania and especially Estonia are leftskewed with more students on the higher end. It may also be of interest to look at how gender may relate to civic knowledge in this middle level. The authors obtained a median civic knowledge score of 518.4 for boys and 520.3 for girls in Latvia, 521.9 for boys and 524.0 for girls in Lithuania, and 523.8 for boys and 527.3 for girls in Estonia. Medians depending on urbanisation level were also calculated: 519.0 (non-urban) and 520.5 (urban) for Latvia, 522.9 (non-urban) and 523.2 (urban) for Lithuania, and 525.8 (non-urban) and 527.5 (urban) for Estonia.

To investigate associations of civic knowledge with other factors, the authors used a multivariable regression analysis. In the following analysis, variation inflation factor (VIF) values are not reported, but this was not above 1.5 for any of the variables in the models considered, i.e. multicollinearity is not an issue for this dataset. When significance is mentioned, the authors mean a $5 \%$ level of statistical significance. In Figure 1, the results of the subsampling simulation are shown. Subsets of 150 students were taken 1000 times for the B level in full, the lower B level and the upper B level. Each dataset model was constructed five times with each of the plausible values as a dependent variable. The corresponding bars in the plot represent how many of those 1000 models had statistically significant predictors. For example, in this case of Latvia, it seems that students' expected educational attainment could be significant for both the lower and upper B level, however test language use at home appears to be more significant at the lower level, and likewise for equal rights for all ethnic 
Čekse \& Alksnis, 2021. The Relationship Between Civic Factors and the Middle Proficiency Level of Civic Knowledge

and racial groups. The dashed line is a $5 \%$ reference line to help differentiate predictors that have been sufficiently significant.

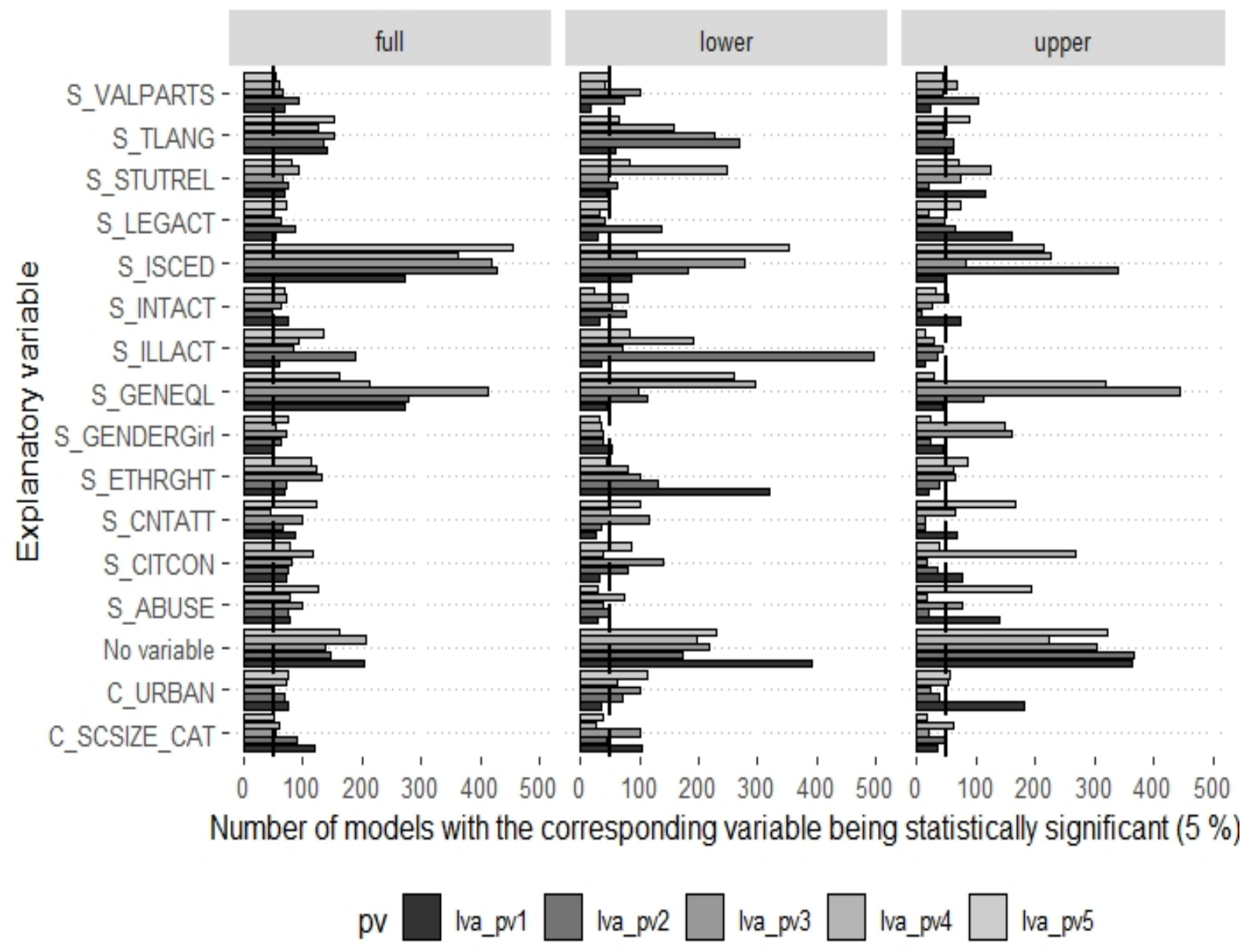

Figure 1 Results of the Subsampling Simulation on Latvian Students

Based on the simulation above, a regression model was constructed for each case. For the whole B level, based on the plot above, the authors included test language use at home, expected educational attainment and endorsement of gender equality, the student's experience of physical or verbal abuse, and endorsement of equal rights for all ethnic and racial groups as factors in the model. This model had an adjusted R-squared of 3.5\% which indicates low explanatory power, however in this study, the model is used for inferential purposes and not for prediction as it is the significance of the predictors that is mostly of interest. Therefore, no R-squared values are reported since all were in the range of 1-5\%. In this final model, only S_ISCED and S_GENEQL can be considered as statistically significant. This may be concluded by p-values but, more importantly, by the asymmetry of confidence intervals, which indicates a positive association. 
SOCIETY. INTEGRATION. EDUCATION

Proceedings of the International Scientific Conference. Volume II, May $28^{\text {th }}-29^{\text {th }}$, 2021. 151-164

Table 2 Linear Regression Models for Students of the Middle Proficiency Level of Civic Knowledge

\begin{tabular}{|c|c|c|c|c|}
\hline Variable & Std. error & Estimate & Conf. interval & $p$-value \\
\hline \multicolumn{5}{|c|}{ Latvia } \\
\hline S_GENEQL & 0.31 & 0.75 & $(0.03,1.46)$ & 0.04 \\
\hline S_ISCED & 3.89 & 8.84 & $(-0.55,18.23)$ & 0.06 \\
\hline S_TLANG & 11.46 & -1.92 & $(-25.62,21.79)$ & 0.87 \\
\hline S_ABUSE & 0.19 & -0.16 & $(-0.57,0.24)$ & 0.41 \\
\hline S_ETHRGHT & 0.31 & 0.26 & $(-0.38,0.91)$ & 0.41 \\
\hline \multicolumn{5}{|c|}{ Lithuania } \\
\hline S_VALPARTS & 0.36 & 0.27 & $(-0.61,1.14)$ & 0.49 \\
\hline S_STUTREL & 0.19 & -0.04 & $(-0.43,0.35)$ & 0.85 \\
\hline S_LEGACT & 0.20 & 0.23 & $(-0.18,0.63)$ & 0.27 \\
\hline S_ISCED & 6.06 & 11.42 & $(-3.73,26.56)$ & 0.11 \\
\hline S_ILLACT & 0.30 & -0.73 & $(-1.42,-0.04)$ & 0.04 \\
\hline S_GENEQL & 0.30 & 0.80 & $(0.11,1.47)$ & 0.03 \\
\hline S_GENDER & 4.51 & -5.32 & $(-14.89,4.26)$ & 0.26 \\
\hline S_ETHRGHT & 0.19 & 0.24 & $(-0.16,0.63)$ & 0.23 \\
\hline S_CNTATT & 0.17 & -0.40 & $(-0.74,-0.05)$ & 0.02 \\
\hline S_CITCON & 0.23 & -0.04 & $(-0.52,0.43)$ & 0.86 \\
\hline S_ABUSE & 0.22 & -0.17 & $(-0.65,0.31)$ & 0.46 \\
\hline C_URBAN & 3.06 & -0.18 & $(-6.21,5.86)$ & 0.95 \\
\hline C_SCSIZE_CAT & 1.85 & 1.49 & $(-2.27,5.24)$ & 0.43 \\
\hline S_TLANG & 9.84 & 6.11 & $(-13.56,25.77)$ & 0.54 \\
\hline \multicolumn{5}{|c|}{ Estonia } \\
\hline S_LEGACT & 0.29 & 0.33 & $(-0.28,0.94)$ & 0.28 \\
\hline S_ISCED & 2.72 & 6.63 & $(0.78,12.47)$ & 0.03 \\
\hline S_ILLACT & 0.28 & -0.50 & $(-1.07,0.07)$ & 0.09 \\
\hline S_GENEQL & 0.41 & 1.08 & $(0.10,2.05)$ & 0.03 \\
\hline S_ABUSE & 0.20 & -0.24 & $(-0.65,0.16)$ & 0.23 \\
\hline
\end{tabular}

It appears that students with higher expected educational attainment on average tend to score higher on the civic knowledge test. Endorsement of gender equality is also associated with a higher level of civic knowledge. Test language use at home, although not significant at the 5\% level in this final model, may however have a negative association since it was significant in more than $15 \%$ of the models constructed.

Following the same procedure for Lithuania, the authors constructed a model with fourteen predictors of which three (S_ILLACT, S_CNTATT and S_GENEQL) appear to be significant, with the first two being negatively related to civic knowledge and the latter one positively. However, through confidence intervals, some other associations may also be noticed. S_TLANG may be 
Čekse \& Alksnis, 2021. The Relationship Between Civic Factors and the Middle Proficiency Level of Civic Knowledge

positively associated with civic knowledge, which means that native-speaking Lithuanian students on average score higher on the civic knowledge test. One of the main factors is S_ILLACT, which is negatively associated with civic knowledge. Lithuanian students who are expected to participate in illegal activities tend to score lower. Positive attitudes towards Lithuania seem to be negatively associated with civic knowledge, which indicates that more patriotic students on average score lower, while participation at school is related to higher knowledge on average. School size also seems to have some effect, indicating higher civic knowledge for those at larger schools.

The same steps were applied to the Estonia dataset, and a model with five predictors was obtained. Three (S_ISCED, S_ILLACT and S_GENEQL) appear to be significant (at a 10\% confidence level), and it seems that S_LEGACT may have some positive association and S_ABUSE a negative association. One thing in common to all three countries is that endorsement of gender equality and expected educational attainment are two of the main factors that have some association with civic knowledge. Similarly to Lithuania, Estonian students on average score lower if they expect to participate in illegal activities and protests.

Table 3 Linear Regression Models for Students with a Lower Middle Proficiency Level of Civic Knowledge

\begin{tabular}{|c|c|c|c|c|}
\hline Variable & Std. error & Coefficient & Conf. int. & p-value \\
\hline \multicolumn{5}{|c|}{ Latvia } \\
\hline S_TLANG & 9.62 & 2.79 & $(-17.07,22.65)$ & 0.77 \\
\hline S_ISCED & 4.16 & 4.07 & $(-5.20,13.33)$ & 0.35 \\
\hline S_ABUSE & 0.26 & 0.04 & $(-0.50,0.57)$ & 0.88 \\
\hline S_ILLACT & 0.37 & -0.44 & $(-1.30,0.42)$ & 0.27 \\
\hline S_GENEQL & 0.34 & 0.44 & $(-0.30,1.18)$ & 0.23 \\
\hline S_ETHRGHT & 0.31 & -0.01 & $(-0.64,0.61)$ & 0.97 \\
\hline S_STUTREL & 0.25 & 0.20 & $(-0.33,0.72)$ & 0.46 \\
\hline \multicolumn{5}{|c|}{ Lithuania } \\
\hline S_VALPARTS & 0.36 & 0.37 & $(-0.47,1.22)$ & 0.34 \\
\hline S_ISCED & 6.63 & 11.50 & $(-4.23,27.22)$ & 0.12 \\
\hline S_ILLACT & 0.27 & -0.43 & $(-1.00,0.15)$ & 0.14 \\
\hline S_GENEQL & 0.45 & 0.63 & $(-0.42,1.67)$ & 0.20 \\
\hline S_INTACT & 0.29 & -0.26 & $(-0.93,0.42)$ & 0.41 \\
\hline S_CITCON & 0.26 & -0.03 & $(-0.57,0.51)$ & 0.90 \\
\hline S_ABUSE & 0.33 & -0.19 & $(-0.94,0.56)$ & 0.58 \\
\hline \multicolumn{5}{|c|}{ Estonia } \\
\hline S_GENEQL & 0.63 & 0.81 & $(-0.71,2.34)$ & 0.24 \\
\hline S_CNTATT & 0.24 & -0.01 & $(-0.51,0.49)$ & 0.96 \\
\hline S_CITCON & 0.33 & 0.26 & $(-0.44,0.98)$ & 0.43 \\
\hline S_ABUSE & 0.27 & -0.14 & $(-0.68,0.39)$ & 0.59 \\
\hline
\end{tabular}


The authors will now investigate the differences between the lower and higher proficiency levels of civic knowledge within and across Baltic countries. First, we compare the lower levels. By applying the same steps as above for Latvian students with a lower proficiency level, we constructed a linear model with seven predictors (see Table 3).

It seems that the model has an extremely poor fit; none of the seven predictors are significant at a $10 \%$ significance level. However, expected educational attainment and endorsement of gender equality seem to have some positive association with civic knowledge, while S_ILLACT appears to be negatively related.

For Lithuanian students, we constructed a model with seven predictors (see Table 3). Confidence intervals indicate a possible positive association for S_VALPARTS, S_GENEQL and S_ISCED and a negative one for S_ILLACT. Due to the symmetry of the other three confidence intervals, S_INTACT, S_CITCON and S_ABUSE cannot be considered to have any effect.

For Estonian students, a model with four explanatory variables was constructed, of which S_GENEQL appears to have some positive effect.

Table 4 Linear Regression Models for Students with a Higher Middle Proficiency Level of Civic Knowledge

\begin{tabular}{|c|c|c|c|c|}
\hline Variable & Std. error & Coefficient & Conf. int. & p-value \\
\hline \multicolumn{5}{|c|}{ Latvia } \\
\hline S_ISCED & 5.87 & 7.35 & $(-6.17,20.88)$ & 0.25 \\
\hline S_GENEQL & 0.42 & 0.52 & $(-0.44,1.47)$ & 0.25 \\
\hline S_ABUSE & 0.31 & -0.23 & $(-0.92,0.47)$ & 0.49 \\
\hline S_TLANG & 17.57 & -11.52 & $(-48.77,25.72)$ & 0.52 \\
\hline S_STUTREL & 0.24 & -0.17 & $(-0.64,0.31)$ & 0.49 \\
\hline \multicolumn{5}{|c|}{ Lithuania } \\
\hline S_ISCED & 6.25 & 9.85 & $(-5.48,25.18)$ & 0.17 \\
\hline S_ILLACT & 0.41 & -0.56 & $(-1.56,0.44)$ & 0.22 \\
\hline S_GENDER & 5.55 & -4.76 & $(-16.50,6.98)$ & 0.40 \\
\hline S_ABUSE & 0.22 & -0.10 & $(-0.55,0.35)$ & 0.66 \\
\hline S_GENEQL & 0.32 & 0.35 & $(-0.36,1.05)$ & 0.31 \\
\hline S_ETHRGHT & 0.26 & 0.29 & $(-0.26,0.84)$ & 0.29 \\
\hline C_SCSIZE_CAT & 3.46 & 1.90 & $(-5.79,9.60)$ & 0.60 \\
\hline C_URBAN & 3.78 & 4.24 & $(-3.36,11.84)$ & 0.27 \\
\hline \multicolumn{5}{|c|}{ Estonia } \\
\hline S_STUTREL & 0.31 & -0.13 & $(-0.75,0.49)$ & 0.67 \\
\hline S_ISCED & 5.26 & 8.23 & $(-3.97,20.45)$ & 0.15 \\
\hline S_GENDER & 6.30 & -7.27 & $(-20.69,5.23)$ & 0.23 \\
\hline S_ABUSE & 0.27 & -0.14 & $(-0.70,-0.40)$ & 0.58 \\
\hline S_ETHRGHT & 0.37 & 0.30 & $(-0.44,1.06)$ & 0.41 \\
\hline
\end{tabular}


Čekse \& Alksnis, 2021. The Relationship Between Civic Factors and the Middle Proficiency Level of Civic Knowledge

When the higher-middle proficiency level was investigated for Latvian students, the authors constructed a linear model with five predictors (see Table 4). Similarly to the above, S_ISCED and S_GENEQL appear to have some positive association. Judging again by the asymmetry of the confidence intervals, S_TLANG is negatively associated and, likewise, S_ABUSE and S_STUREL.

The model for Lithuanian students with a higher middle proficiency level was constructed with eight predictors. As in all instances above, S_ISCED and endorsement of gender equality seem to have a positive association. In this case, urbanisation level and endorsement of equal rights for all ethnic and racial groups also appear to have a positive relation with civic knowledge, while gender and S_ILLACT seem to have a negative effect.

Finally, a model with five explanatory variables was constructed for Estonian students. As above, S_ISCED appears to have a positive effect, and endorsement of equal rights for all ethnic and racial groups also seems to be positively related. Gender seems to be negatively associated, meaning that boys tend to score higher on average.

\section{Discussion}

This research was done with the aim of investigating the relationship between civic and citizenship factors and the middle proficiency level of students' civic knowledge in the Baltic countries. The results show that there may be some relationship between student and school factors and the middle proficiency level of civic knowledge. The three Baltic countries considered share some similarities - for example, expected educational attainment seems to be positively related with higher achievements on civic knowledge tests in all instances above - but there are also some factors such as language used at home and participation in illegal activities that indicated some differences.

There were factors that were highlighted in the middle proficiency level of civic knowledge in general but which are not detected when analysing the higher middle and lower middle proficiency levels separately: Estonian students do not have a relationship with willingness to take part in illegal protest activities, and Lithuanian students have value factors that report them as having positive attitudes towards their country's flag and their sense of belonging to the country.

The results show that there are different factors that are associated with the highest and lowest achievements in the middle proficiency level. There are four outcomes to emphasise.

First, for Latvian students, expected participation in illegal activities seems to have some effect only in the lower proficiency level of civic knowledge, while there are a few that appear only in the higher middle level, such as 
experience of abuse at school, test language use at, home and student-teacher relations at school. Endorsement of gender equality and expected educational attainment seem to be important factors in the lower as well as higher B level. What can be noticed about Lithuania is that both expected educational attainment and expected participation in illegal activities appear in the lower as and higher B levels. However, students' perception of the value of participation at school and experience of abuse at school seem to have some effect only at the lower proficiency level, while at the higher level, background factors such as gender, urbanisation and school size appear.

Our results show that Estonia and Lithuania are those Baltic countries where gender seems to be associated with civic knowledge at higher proficiency levels. In general, ICCS 2016 demonstrates that civic knowledge has a significant relationship with students' gender in 19 of the 24 participating countries (Schulz et al., 2017). There are similar findings in other IEA and PISA comparative surveys (Baye \& Monseur, 2016). For example, PIRLS 2016 shows a tight relationship between reading literacy and gender (Nonte, 2018).

Second, we can see more positive attitudes towards gender equality from students with a middle proficiency level of civic knowledge. Also, we can see that students' expected educational attainment is a significantly important factor in the middle proficiency level.

Third, experience of physical or verbal abuse seems to be an important factor for all three countries, but this also somehow divides the middle proficiency level because it appears to be important when the whole $\mathrm{B}$ level is considered but not as much when the lower and upper B levels are investigated separately. The results show that those students who are in the lower middle proficiency level acknowledge the existence of violence in the school and classroom environment more often. All the results of the Baltic countries show the importance of this factor. There are other surveys that have indicated similar observations about the relationship between victimhood and achievements. A large-scale longitudinal study of TIMSS results from Italy also highlighted that the effect of being a victim of school violence on student achievement is larger for students at the age of 13 than at the age of 9 (Ponzo, 2013), and the Canadian National Longitudinal Survey of Children and Youth shows that children who are bullied at school are likely to obtain low levels of achievement (Beran, Hughes, Ginger, \& Lupart, 2008). Another study's results show the adverse impact of perceived safety and community violence exposure on primary school children's academic performance (Milam, Furr-Holden, \& Leaf, 2010). Hypothetically, according to the study results, we can accept that the systematic reduction of any violence can be a reason that will help students to rise up from the lower to the higher middle proficiency level of civic knowledge. Our findings provide guidance for education policy-makers to develop anti-violence 
Čekse \& Alksnis, 2021. The Relationship Between Civic Factors and the Middle Proficiency

Level of Civic Knowledge

and emotional intelligence programmes as a precondition to get higher levels of students' civic knowledge and support both students who have had experience of violence and students who are violent.

Forth, since the country context is highlighted as an important factor in ICCS 2009 (Diazgranados Ferrans, 2016), our study supports other authors' findings according to ICCS 2016 data (Schulz et al., 2017). We found evidence that the country context is significant in the lower middle proficiency level because there are different factors that affect it. For example, significant important factors in the Estonian context are gender and living in highly populated areas. The significance of gender was also found in relationships between the efficacy beliefs and civic knowledge variables (Lucidi \& Alivernin, 2014). For the Lithuanian context, the study's results highlighted radical citizenship activities. Lithuanian students in the lower middle proficiency level mentioned the importance of conventional citizenship activities, while Latvian students mentioned ethnic rights.

This study has demonstrated the relationship between civic factors and the lower and higher middle proficiency levels of civic knowledge using the examples of Estonia, Lithuania and Latvia. The research investigated differences inside the middle proficiency level of civic knowledge and explored the differences between the lowest middle-level students and students from the lower level of civic knowledge. The results lead the authors to draw the conclusion that when analysing factors by proficiency level, students must be divided into two in each of the civic knowledge levels to show the similarities between the lower higher proficiency level and higher middle proficiency level and the higher lower proficiency level and lower middle proficiency level.

\section{Acknowledgements}

This research was funded by the "Post-doctoral Research Aid" project No 1.1.1.2/VIAA/1/16/00, research application No. 1.1.1.2/VIAA/1/16/020.

\section{References}

Baye, A., Monseur, C. (2016). Gender Differences in Variability and Extreme Scores in an International Context. Large-scale Assessments in Education, 4(1) 1-16

Beran, T.N., Hughes, G., Lupart, J. (2008). A Model of Achievement and Bullying: Analyses of the Canadian National Longitudinal Survey of Children and Youth Data. Educational Research, 50(1), 25-39. DOI: 10.1080/00131880801920379

Creemers, M. (1994). The Effective Classroom. London: Cassell.

Carolyn, B., Torney-Purta, J., \& Wilkenfeld, B. R. (2015). Immigrant and Native-born Adolescents' Civic Knowledge and Attitudes in Sweden and the United States: 
Emergent Citizenship within Developmental Niches. Research in Comparative and International Education, 10(1), 23-47.

Council of Europe. (2019). Digital Citizenship Education Handbook. Council of Europe.

Diazgranados Ferrans, S. (2016). The Civic Knowledge Gaps in Chile, Colombia and Mexico: An Application of the Oaxaca-Blinder Decomposition Method Using Data From the 2009 International Civic and Citizenship Education Study (ICCS). Ed.D. diss., Harvard Graduate School of Education.

Diego, C., Banerjee, R., Treviño, E., \& Villalobos, C. (2020). Civic Knowledge and Open Classroom Discussion: Explaining Tolerance of Corruption among 8th-grade Students in Latin America. Educational Psychology, 40(2), 186-206.

Kirlin, M. (2003). The Role of Civic Skills in Fostering Civic Engagement. Washington, DC: CIRCLE.

Knowles, T.R., \& McCafferty-Wright, J. (2015). Connecting an open classroom climate to social movement citizenship: A study of 8th graders in Europe using IEA ICCS data. Journal of Social Studies Research, 39(4), 255-269. https://doi.org/10.1016/ j.jssr.2015.03.002

Köhler, H., Weber, S., Falk, B., Schulz, W., \& Carstens, R. (2018). ICCS 2016 User Guide for the International Database. Amsterdam: IEA .

Isac, M.M.; Maslowski, R.; van der Werf, G. (2011). Effective civic education: an educational effectiveness model for explaining students' civic knowledge. School Effectiveness and School Improvement, 22(3), 313-333.

Lihong, H., \& Biseth, H. (2016). Openness in Scandinavian Classrooms: Student Perceptions of Teaching Practices and High Achievers of Civic Knowledge. Creative Education, 7(5), 713-723.

Lin, A. (2015). Citizenship education in American schools and its role in developing civic engagement: a review of the research. Educational Review, 67(1), 35-63.

Lucidi, M.S., \& Alivernin. (2014). Adolescents' Expected Civic Participation: The Role of Civic Knowledge and Efficacy Beliefs. Journal of Adolescence, 37(5), 632-641.

Manganelli, S., \& Lucidi, A. (2015). Italian Adolescents' Civic Engagement and Open Classroom Climate: The Mediating Role of Self-efficacy. Journal of Applied Developmental Psychology, 41, 8-18.

Manganelli, S., Lucidi, F., \& Alivernin, F. (2014). Adolescents' Expected Civic Participation: The Role of Civic Knowledge and Efficacy Beliefs. Journal of Adolescence, 37(5), 632-41.

Manning, N., \& Edwards, K. (2014). Does civic education for young people increase political participation? A systematic review. Educational Review, 66(1), 22-45. doi:10.1080/00131911.2013.763767

Milam, A., Furr-Holden, C., \& Leaf, P. (2010). Perceived School and Neighborhood Safety, Neighborhood Violence and Academic Achievement in Urban School Children. Urban Review, 42(5), 458-67.

Mycock, A., \& Tonge, J. (2012). The Party Politics of Youth Citizenship and Democratic Engagement. Parliamentary Affairs, 65(1), 138-161. https://doi.org/10.1093/pa/gsr053

Ponzo, M. (2013) Does Bullying Reduce Educational Achievement? An Evaluation Using Matching Estimators. Journal of Policy Modeling, 35(6), 1057-1078. https://doi.org/ 10.1016/j.jpolmod.2013.06.002

Schulz, W., Ainley, J., Losito, B., \& Agrusti, G. (2016). Assessment Framework. Cham: Springer Open. 
Čekse \& Alksnis, 2021. The Relationship Between Civic Factors and the Middle Proficiency Level of Civic Knowledge

Schulz, W., Ainley, J., Fraillon, J., Losito, B., Agrusti, G., \& Tim, F. (2017). Becoming Citizens in a Changing World: IEA International Civic and Citizenship Education Study 2016 International Report. Cham: Springer.

Torney-Purta, J. (2002). The School's Role in Developing Civic Engagement: A Study of Adolescents in Twenty-Eight Countries. Applied Developmental Science, 6(4), 203-212. doi:10.1207/S1532480XADS0604_7

Torney-Purta, J.; Lehman, R.; Oswald, H.; Schulz, W. (2001). Citizenship and Education in Twenty-Eight Countries: Civic Knowledge and Engagement at Age Fourteen. Amsterdam: IEA.

Veugelers, W., \& Groot, I. (2019). Theory and Practice of Citizenship Education. In W. Veugelers (Ed.), Education for Democratic Intercultural Citizenship (pp. 14-41). Leidlen; Boston: Brill.

Whiteley, P. (2014). Does Citizenship Education Work? Evidence from a Decade of Citizenship Education in Secondary Schools in England. Parliamentary Affairs, 67(3), 513-535. doi: https://doi.org/10.1093/pa/gss083

Zhu, J., \& Chiu, M. M. (2020). Immigrant students in Denmark: why are they disadvantaged in civic learning? Educational Psychology, 40(2), 207-226. doi:10.1080/ 01443410.2019.1657560 